\section{Bronzing of Strawberry Fruit as Affected by Production Practices, Environmental Factors, and Thrips}

\author{
Steven T. Koike ${ }^{1}$ \\ University of California Cooperative Extension, 1432 Abbott Street, Salinas, \\ CA 93901
}

Frank G. Zalom

Department of Entomology, University of California, One Shields Avenue, Davis, CA 95616

Kirk D. Larson

University of California South Coast Research and Extension Center, 7601 Irvine Boulevard, Irvine, CA 92618

Additional index words. Fragaria $\times$ ananassa, Frankliniella occidentalis Pergrande, irrigation, lignin, polyethylene mulch, pesticide, solar injury, ultraviolet radiation

\begin{abstract}
Strawberry fruit are subject to three different types of bronzing damage that cause discoloration of the fruit surface and loss of market quality. Type I and Type II bronzing both occur in localized areas of the fruit and are caused by arthropod feeding and chemical phytotoxicity, respectively. In contrast, Type III bronzing (T3B) covers the entire fruit and is associated with environmental and plant stress factors, although many growers and crop advisers believe that T3B is caused by thrips feeding. The purpose of our 3-year study was to investigate incidence of T3B as affected by crop management practices and thrips populations. Replicated field trials demonstrated that overhead cooling with sprinklers resulted in a significant reduction in T3B incidence. In addition, a series of foliar pesticide spray applications also resulted in reduced T3B damage to strawberry fruit. Foliar applications of Thiolux sulfur, other registered pesticides, and lignin products all resulted in reduced incidence of T3B in field trials. In contrast, T3B incidence was not associated with thrips populations; insecticide-treated plots had reduced thrips populations and comparable T3B incidence to nontreated plots that had greater thrips populations. Our study provides evidence that T3B occurrence is associated with exposure to elevated temperatures and solar radiation rather than thrips feeding and that growers can reduce T3B incidence by implementing production practices that reduce plant stress and protect fruit from radiation damage.
\end{abstract}

California accounts for over $80 \%$ of total U.S. strawberry (Fragaria $\times$ ananassa) production. In 2008, strawberry production on 14,780 ha in California was valued at over \$2.3 billion (Processing Strawberry Advisory Board of California, 2008). Approximately $40 \%$ of California's strawberry crop is produced in the central coast region of the state (lat. $\approx 37^{\circ} \mathrm{N}$ ); in this region, bronzing of strawberry fruit often occurs between late spring and midsummer. Bronzing is the term used to describe damage to outer tissues of immature, green or mature fruit and in which

Received for publication 30 Apr. 2009. Accepted for publication 9 July 2009 .

Financial support for this study was provided by the California Strawberry Commission.

We thank the following for their assistance: Riesa Bigelow, Brian Caster, David Delgado, Teo Gonzales, Esther Guedea, Diana Henderson, Dave Limburg, Gary Omori, Ed Show, Tom Sjulin, Richard Uyematsu, David Vasquez, Elia Vasquez, and Frank Westerlund.

${ }^{1}$ To whom reprint requests should be addressed; e-mailstkoike@ucdavis.edu.
(Frankliniella occidentalis Pergrande) or cyclamen mite (Phytonemus pallidus Banks); damage typically occurs on receptacle tissues beneath the calyx or around the achenes (Allen and Gaede, 1963; Maas, 1998). Type II bronzing (Fig. 1B) results from damage caused by chemical sprays, often as a result of repeated applications of sulfur or other compounds that can be phytotoxic under certain conditions. For both I and II types, bronzing occurs in localized areas of the fruit surface that have been directly exposed to the arthropod feeding or chemical contact, and damage is readily correlated with recent arthropod activity or chemical applications.

In contrast, Type III bronzing (T3B) covers the entire fruit surface (Fig. 1C). Results of anatomical and histochemical examinations indicate that $\mathrm{T} 3 \mathrm{~B}$ damage resembles sun scald injury and is likely a response to heat or solar radiation (Polito et al., 2002). Importantly, T3B typically occurs in California's central coast strawberry production areas when periods of high irradiance, high temperatures, and low relative humidity may occur. The problem is observed more frequently in inland areas than in coastal ranches that have cooler, overcast weather, suggesting that environmental conditions are likely factors in the development of T3B. During periods of T3B occurrence, economic losses can be significant and up to $70 \%$ T3B incidence has been documented. Some growers and researchers have observed that T3B incidence tends to be most pronounced after cold winters that result in reduced plant canopy development, reduced shading within the plant, and increased irradiance levels within the plant canopy.

Field research has demonstrated that high temperatures and high irradiance are important factors in T3B occurrence and development. Increased plant vegetative growth during the winter establishment period, achieved with use of crop best management practices, enables such plants to better withstand environmental stresses in the spring and summer and resulted in reduced incidence of T3B (Larson et al., 2005, 2006). Despite such findings, many growers and crop advisers associate T3B symptoms with thrips feeding damage. Presently, strawberry growers in California have been unable to predictably prevent or manage the occurrence of bronzing. However, some growers report that applications of sulfur, for powdery mildew control, and insecticides reduced the severity of T3B when such applications were made before periods of T3B occurrence. Because such pesticide materials contain lignins that protect chemicals against solar and ultraviolet radiation, we hypothesized that commercial products provided protection from factors that caused T3B.

The purpose of the studies described subsequently was to test whether occurrence of T3B is associated with greater thrips densities and whether management practices such as supplemental irrigation or chemical applications can reduce $\mathrm{T} 3 \mathrm{~B}$. 

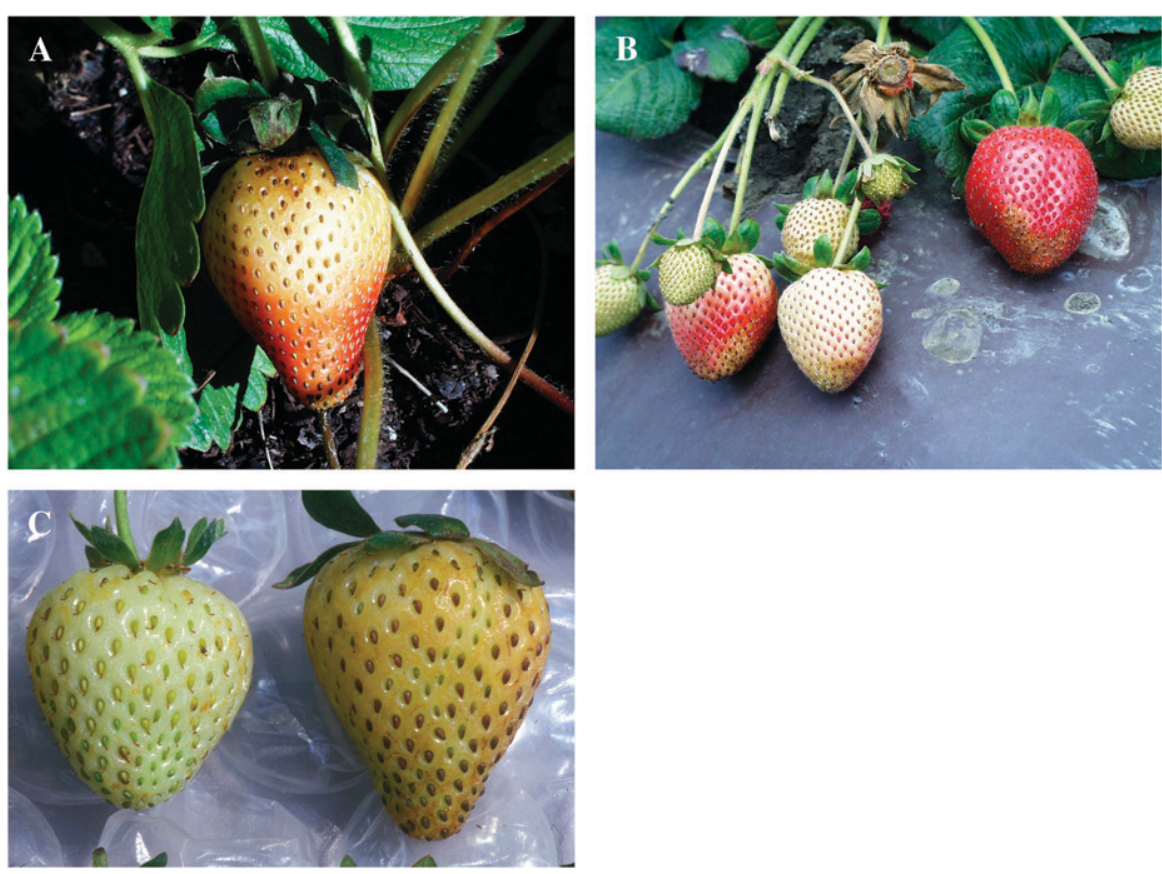

Fig. 1. Localized Type I bronzing caused by arthropod feeding (A); localized Type II bronzing on the tips of fruit caused by chemical burn (B); Type III bronzing (right) and unaffected strawberry fruit (left) (C)

Table 1. Commercial pesticide applications made to 2001 bronzing field trials: Sites 1 and 2. ${ }^{z}$

\begin{tabular}{llclll}
\hline \multicolumn{5}{c}{ Application dates } \\
\hline 13 Apr. & 26 Apr. & 3 May & \multicolumn{1}{c}{17 May } & \multicolumn{1}{c}{ 25 May } & 31 May \\
\hline Agri-mek & Agri-mek & Lannate & AcidipHactant & AcidipHactant & AcidipHactant \\
& AZA Direct & & Dibrom & Agri-mek & Elevate \\
& Elevate & & Elevate & E-Rase & Lannate \\
& Pyganic & & Rally & Silwet & Rally \\
& Rally & & & Silwet \\
& Silwet & & & \\
\hline
\end{tabular}

${ }^{2}$ Spray materials and equivalent rates of product (per $378.5 \mathrm{~L}$ ) are the following: AcidipHactant (surfactant) at $0.18 \mathrm{~L} ;$ Agri-mek (insecticide) at $0.19 \mathrm{~L} ;$ AZA Direct (insecticide) at $0.38 \mathrm{~L}$; Dibrom (insecticide) at 0.19 $\mathrm{L}$; Elevate (fungicide) at $274.5 \mathrm{~g}$; E-Rase (disinfectant) at $1.96 \mathrm{~L}$; Lannate (insecticide) at $183 \mathrm{~g}$; Pyganic (insecticide) at $0.38 \mathrm{~L}$; Rally (fungicide) at $58.9 \mathrm{~g}$; Silwet (surfactant) at $0.13 \mathrm{~L}$.

\section{Materials and Methods}

Bronzing and thrips populations, 2000. To investigate effects of thrips populations on T3B incidence, an experiment was conducted in 2000 in a commercial field near Watsonville, $\mathrm{CA}$. The field was planted in standard commercial fashion with two rows of strawberries ('Commander') per bed. Experimental plots were five beds ( $1 \mathrm{~m}$ per bed) wide $\times$ $77.5 \mathrm{~m}$ long. Treatments were replicated five times and consisted of an unsprayed control and foliar spray combination of Lannate (methomyl, $189 \mathrm{~g} / 378.5 \mathrm{~L}$ water) and malathion (473 mL/378.5 L water) made weekly beginning 17 June. Thrips populations were determined weekly by collecting five strawberry flowers from each plot, washing the flowers in alcohol to dislodge thrips, filtering the alcohol rinsate through filter paper using vacuum extraction, and counting the recovered insects. Thrips were sampled from 17 June (pretreatment sample) to 9 Aug. For all plots, immature green fruit were evaluated weekly for symptoms of T3B from 29 June to 30 Aug., and percentage of T3B fruit was calculated for each treatment and evaluation date.
Data were analyzed by repeated-measures analysis of variance (JMP 7.0; SAS Institute, Cary, NC).

Crop production treatments and bronzing incidence: Site 1. Because T3B appears to be triggered by environmental stress factors, experiments were conducted in commercial fields near Watsonville to evaluate the influence of various crop management practices on T3B incidence. Site 1 was transplanted in a commercial fashion on 27 Dec. 2000 with two rows of strawberry ('Commander') placed in 1-m-wide beds; each bed was irrigated by a single buried $(2.5-\mathrm{cm}$ depth) drip irrigation tube. We imposed various treatments to increase or reduce stress to the plants. The experiment was a randomized complete block split-plot design; the two main plots either received supplemental overhead watering (15 min twice a week from 23 Apr. to 21 June) to cool plants or had no supplemental cooling. Subplots were replicated four times and were one bed wide $(1 \mathrm{~m}) \times 10.1 \mathrm{~m}$ long. Subplot treatments were the following: 1) clear, full bed mulch applied Dec. 2000; 2) clear, center strip mulch applied Mar. 2001; 3) gray-green, full bed mulch applied Dec. 2000; 4) foliar pesticides (Table 1) applied commercially six times; 5) deficit irrigation scheduling with no drip irrigation from 11 Apr. to 4 June; and 6) beds completely enclosed with $50 \%$ shadecloth supported on hoops to provide shading from solar radiation. The commercial pesticide regime was the same as was applied to the area of the grower's field outside of the experimental plots.

For all plots, immature green fruit were evaluated twice a week for symptoms of T3B from 7 May to 29 June. Mean cumulative totals of T3B fruit were calculated for all 16 evaluation dates. Data were analyzed by oneway analysis of variance and means separated by Student's $t$ test (JMP 7.0; SAS Institute).

Crop production treatments and bronzing incidence: Site 2. Site 2 was prepared and planted in Dec. 2000 in a similar fashion as Site 1. We imposed various treatments to increase or reduce stress to the plants. The experiment was a randomized complete block split-plot design; the two main plots either received supplemental furrow irrigation (at 10- to 14-d intervals from 20 Mar. to 14 June) or had no supplemental watering. The extra furrow water was applied until full bed moisture was attained. Subplots were replicated three times and were one bed wide $(1 \mathrm{~m}) \times 10.1 \mathrm{~m}$ long. Subplot treatments were the following: 1) untreated control; 2) foliar pesticides applied commercially six times (same materials and application dates as for Site 1; Table 1); 3) removal of all but the four youngest leaves; 4) lignin foliar spray applications [a combination of the products Reax 83A, Reax 80D, and Kraftsperse 25M (Westvaco Corp., Charleston Heights, SC), each at $458 \mathrm{~g} / 378.5 \mathrm{~L}$ water, plus Silwet surfactant, applied weekly from 13 Apr. to 6 June]; 5) Thiolux sulfur foliar applications (908 g/ $378.5 \mathrm{~L}$; applied weekly from 13 Apr. to 6 June); and 6) supplemental ammonium sulfate $\left[\mathrm{NH}_{(4) 2} \mathrm{SO}_{4}\right]$ at $67.3 \mathrm{~kg} \mathrm{~N} / \mathrm{ha}$ applied $8 \mathrm{Feb}$. The three chemical application treatments (commercial pesticide program, lignin, and Thiolux sulfur) were included because growers repeatedly observed apparent decreases in T3B problems if chemical applications were made before periods of $\mathrm{T} 3 \mathrm{~B}$ occurrence.

Immature green fruit were evaluated twice a week for symptoms of T3B from 7 May to 29 June, and mean cumulative totals of T3Bdamaged fruit were calculated. In addition, thrips abundance was determined weekly by collecting five strawberry flowers from each plot and processing them to extract thrips, as mentioned previously. Thrips were sampled in this manner on five dates from 3 May to 11 June. T3B data were analyzed as described previously for fruit evaluations. Thrips data were analyzed by repeated-measures analysis of variance (JMP 7.0; SAS Institute).

Treatments for protecting fruit from solar radiation. Results for the two 2000-2001 field trials indicated that the commercial pesticide spray program, lignin, and Thiolux sulfur treatments resulted in reduced T3B on strawberry fruit. Therefore, a third field 
experiment was established in a commercial strawberry field ('Commander') near Watsonville to confirm previous results. The field was planted in Winter 2001 and grown following commercial practices. The experiment was a randomized complete block design with four replications and plots measuring two beds ( $1 \mathrm{~m}$ per bed) wide $\times 10.1 \mathrm{~m}$ long. Treatments applied in 2002 were the following: 1) unsprayed control; 2) lignin Reax 83A (2.88 $\left.\mathrm{kg} \cdot \mathrm{ha}^{-1}\right)$; 3) lignin Kraftsperse 25M (2.88 $\left.\mathrm{kg} \cdot \mathrm{ha}^{-1}\right)$; 4) lignin combination of Reax 83A and Kraftsperse $25 \mathrm{M}$ (2.88 $\mathrm{kg} \cdot \mathrm{ha}^{-1}$ each); 5) Thiolux sulfur (908 g.ha $\left.{ }^{-1}\right)$; 6) commercial pesticide program (malathion at $473 \mathrm{~mL} /$ 378.5 L water and Agri-mek at 0.19 L/378.5 $\mathrm{L}$ water); and 7) removal of all but the four youngest leaves. The lignin and Thiolux sulfur sprays were applied weekly beginning 5 June. Like with the 2001 studies, the commercial pesticide program consisted of the same products, rates, and timing as those applied by the grower to the remainder of the field that was not part of the experimental area.

Immature green fruit were evaluated weekly for presence of T3B symptoms beginning 4 June. T3B was observed on 10 July and 17 July, and on those dates, more extensive sampling was conducted. All green fruit were examined and categorized as nonbronzed or T3B-damaged. Thrips abundance was determined as mentioned previously. Thrips were sampled weekly from 11 June to 16 July. Data were analyzed by one-way analysis of variance and treatment means compared with untreated by pairwise $t$ tests (JMP 7.0; SAS Institute). Thrips data were again analyzed by repeated-measures analysis of variance.

\section{Results}

Bronzing and thrips populations, 2000. Thrips were present in all plots and on all sampling dates from 17 June to 9 Aug. Mean numbers of thrips per strawberry flower in unsprayed plots were significantly greater than for plots treated with the methomyl and malathion tank mix on the 21 June, 28 June, 2 Aug., and 9 Aug. sampling dates (Fig. 2A). With the exception of the initial T3B evaluation date of 29 June, the proportion of strawberry fruit with T3B did not differ significantly between the nontreated and sprayed plots (Fig. 2B).

Crop production treatments and bronzing incidence: Site 1. Five of the six treatments that did not receive overhead sprinkling to cool the plants and fruit had significantly greater total T3B fruit than the corresponding treatments that received overhead sprinkling (Table 2). With no overhead sprinkling, the cumulative number of T3B-affected fruit ranged from 142 to 186 for individual plots in the mulch, deficit irrigation, and shadecloth treatment plots (Table 2). In this main plot, only the plants with the commercial spray applications had T3B damage (59 fruit with T3B) statistically comparable with plants in the overhead sprinkler-cooled plots.
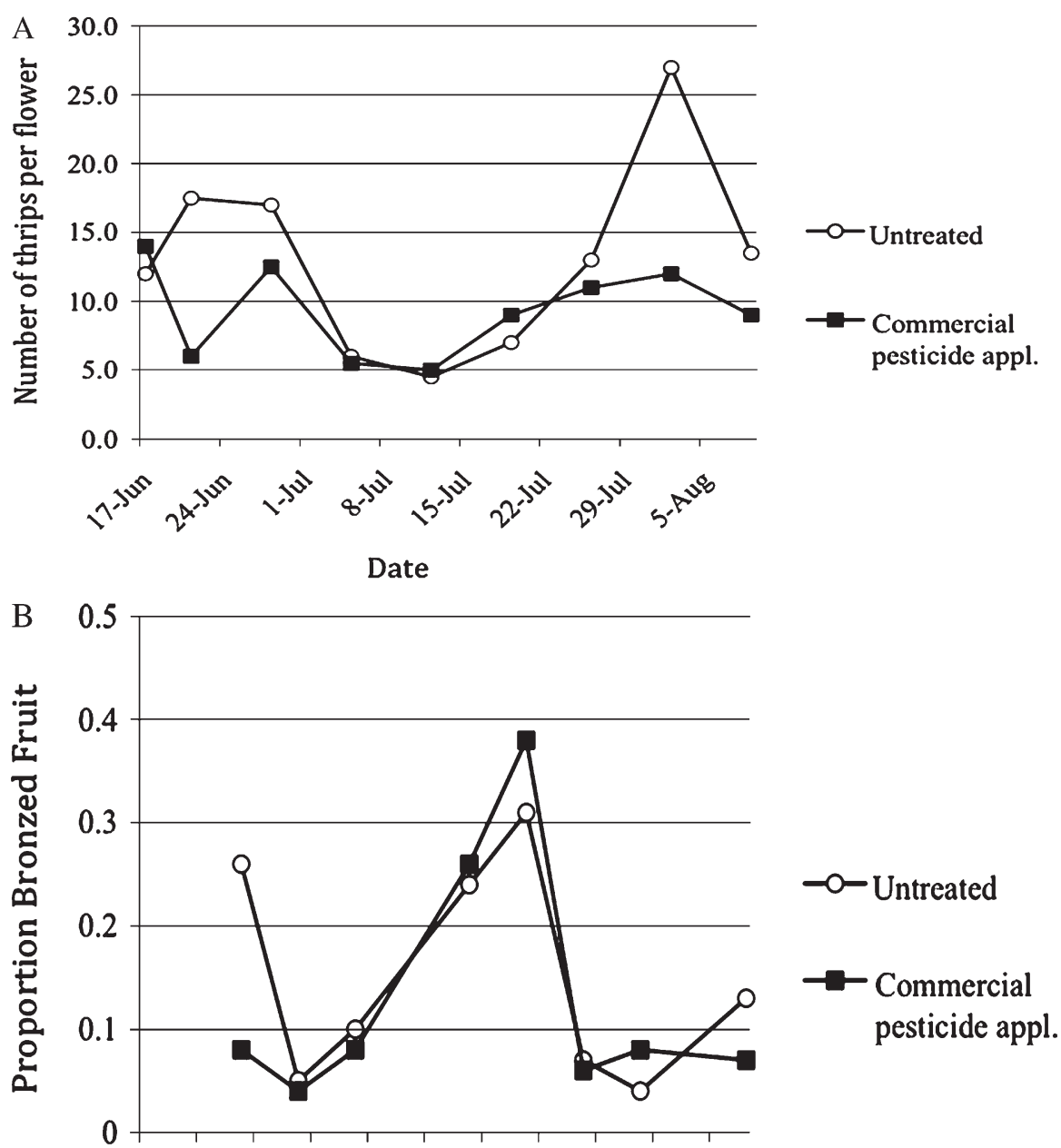

Fig. 2. Thrips abundance (A) and Type III bronzing incidence (B) in a commercial field: 2000.

Table 2. Effect of treatments on bronzed fruit in a commercial field in 2001: Site 1. ${ }^{\mathrm{z}}$

\begin{tabular}{|c|c|c|}
\hline Treatments & $\begin{array}{c}\text { Overhead } \\
\text { sprinkler cooling }\end{array}$ & $\begin{array}{l}\text { Cumulative no. of fruit with T3B } \\
\text { (mean } \pm \text { SEM) }\end{array}$ \\
\hline Clear, full bed mulch; applied in December & No & $142.0 \pm 6.8 \mathrm{~b}$ \\
\hline Clear, center strip mulch; applied in March & No & $176.3 \pm 32.1 \mathrm{ab}$ \\
\hline Commercial pesticide applications & No & $58.5 \pm 5.9 \mathrm{~cd}$ \\
\hline $\begin{array}{l}\text { Gray-green, full bed mulch; applied in } \\
\text { December }\end{array}$ & No & $168.5 \pm 15.8 \mathrm{ab}$ \\
\hline Deficit irrigation scheduling & No & $180.5 \pm 16.4 \mathrm{ab}$ \\
\hline Plants covered with shadecloth hoops & No & $186.3 \pm 14.2 \mathrm{a}$ \\
\hline Clear, full bed mulch; applied in December & Yes & $51.3 \pm 6.7 \mathrm{~cd}$ \\
\hline Clear, center strip mulch; applied in March & Yes & $76.0 \pm 14.8 \mathrm{~cd}$ \\
\hline Commercial pesticide applications & Yes & $41.3 \pm 6.5 \mathrm{~d}$ \\
\hline $\begin{array}{l}\text { Gray-green, full bed mulch; applied in } \\
\text { December }\end{array}$ & Yes & $87.3 \pm 15.4 \mathrm{c}$ \\
\hline Deficit irrigation scheduling & Yes & $78.5 \pm 9.2 \mathrm{~cd}$ \\
\hline Plants covered with shadecloth hoops & Yes & $73.0 \pm 7.8 \mathrm{~cd}$ \\
\hline
\end{tabular}

$\overline{{ }^{2} \text { Mean cumulative number of fruit showing Type III bronzing (T3B) symptoms examined during } 16}$ harvests. Analysis of variance statistics: $\mathrm{F}=14.9474 ; \mathrm{df}=11.47 ; P<0.0001$. Means followed by the same letter are not significantly different by Student's $t$ test at $P<0.05$.

For subplot treatments that received overhead sprinkler cooling, cumulative T3B fruit damage ranged from 41 to 87 (Table 2). Within this group, the plots receiving the commercial pesticide sprays had the lowest T3B damaged fruit (41) in comparison with the mulch, deficit irrigation, and shadecloth treatment plots (Table 2). 
When comparing the two deficit irrigation treatments (no drip irrigation for 8 weeks), plants that received the overhead sprinkler cooling had less than half of the bronzing incidence as did plants that were not cooled (78 and 180, respectively). However, plants that were stressed by the deficit irrigation treatments had smaller fruit and reduced yields.

Crop production treatments and bronzing incidence: Site 2. There were no significant differences in bronzing incidence between supplemental furrow irrigation and no supplemental furrow irrigation $(P=0.7380)$. Therefore, data were combined and analyzed by subplot treatments only. Untreated and supplemental winter nitrogen treatments had greatest total T3B (159 and 135 damaged fruit per plot, respectively) and were not statistically different from each other (Table 3 ). Leaf removal plots had intermediate T3B (87 damaged fruit per plot). The three treatments that involved spray applications had significantly less $\mathrm{T} 3 \mathrm{~B}$ than nontreated plots and did not differ significantly from each other $(47,54$, and 68 damaged fruit per plot for the lignin, Thiolux, and grower's commercial pesticide program, respectively).

Thrips densities monitored from 3 May to 11 June were not associated with the amount of T3B for their respective treatments (Fig. 3A-B). Repeated-measures analysis of variance revealed no significant differences in thrips densities among the untreated, lignin, and commercial pesticide treatments.

T3B fruit were counted twice a week for 8 weeks (7 May to 29 June). During this period, untreated plots had significantly greater numbers of T3B-damaged fruit than plots treated with lignin or commercial pesticides, with the exception of the first two and last three sampling dates when the overall amount of bronzing was relatively low (Fig. 3B). For most of this 8-week period, the amount of T3B-damaged fruit did not differ significantly between lignin and commercial pesticide treatments except for the last two sampling dates when T3B was greater in the commercial pesticide treatment.

Table 3. Effect of treatments on bronzed fruit in a commercial field in 2001: Site 2. ${ }^{\mathrm{z}}$

\begin{tabular}{lc}
\hline Treatment & $\begin{array}{c}\text { Cumulative no. of } \\
\text { fruit with T3B } \\
\text { (mean } \pm \text { SEM) }\end{array}$ \\
\hline Untreated & $159.0 \pm 23.2 \mathrm{a}$ \\
Commercial pesticide & \\
$\quad$ applications & $53.7 \pm 2.8 \mathrm{bc}$ \\
Leaf removal & $87.0 \pm 6.8 \mathrm{~b}$ \\
Lignin sprays & $47.3 \pm 8.6 \mathrm{c}$ \\
Thiolux sulfur sprays & $68.0 \pm 10.7 \mathrm{bc}$ \\
Supplemental winter & \\
$\quad$ nitrogen & $134.8 \pm 15.8 \mathrm{a}$ \\
\hline
\end{tabular}

${ }^{\mathrm{z}}$ Mean cumulative number of fruit showing Type III bronzing (T3B) symptoms examined over 16 evaluations. Main plot treatments were not significantly different, so data were combined and analyzed by subplot treatments. Analysis of variance statistics, $\mathrm{F}=12.1901 ; \mathrm{df}=5.35 ; P<$ 0.0001 .Values followed by the same letter are not significantly different by Student's $t$ test at $P<0.05$.
Treatments for protecting fruit from solar radiation. Fruit evaluations were conducted weekly from 4 June to 17 July 2002. Bronzing incidence was low for most of this period, but T3B-damaged fruit were found on 10 and 17 July, and analysis of variance revealed significant treatment differences on both dates (Table 4). For 10 July, lignin treatments Reax $83 \mathrm{~A}$, Kraftsperse $25 \mathrm{M}$, and their mixture resulted in significantly greater numbers of nonbronzed fruit $(29,28$, and 28 , respectively) than did the untreated control (25). The lignin treatments Reax 83A and Kraftsperse 25M also had significantly fewer T3B fruit $(0.3$ for both) than did the other treatments (Table 4). For 17 July, lignin treatments Reax 83A, Kraftsperse $25 \mathrm{M}$, their mixture, and Thiolux sulfur resulted in significantly greater numbers of nonbronzed fruit $(27,27,28$, and 26 , respectively) than did the untreated control (25). Kraftsperse $25 \mathrm{M}$ and the lignin mixture also had significantly fewer T3B-damaged fruit $(0.2$ for both) than did the other treatments (Table 4). Thrips densities were monitored weekly from 11 June to 16 July (Fig. 4). Repeated-measures analysis of variance revealed no significant differences in thrips abundance between treatments.

\section{Discussion}

Our results are consistent with previous field experiments (Larson et al., 2005, 2006) and anatomical studies (Polito et al., 2002) that indicate environmental stress factors influence or trigger $\mathrm{T} 3 \mathrm{~B}$, suggesting that thrips are not a significant cause of T3B. These findings from commercial field experiments in California therefore do not support the extension bulletins that hypothesize that thrips are responsible for this damage. In our study, plants that received very brief periods of overhead misting or sprinkling to foliage and fruit had consistently less T3B. In a parallel study, T3B was not reduced with supplemental furrow irrigations that watered only the soil and roots. These findings show that T3B is not linked to soil moisture, but to aboveground conditions surrounding the leaves and fruit.

In our studies, modification of the foliage and fruit environment reduced incidence of
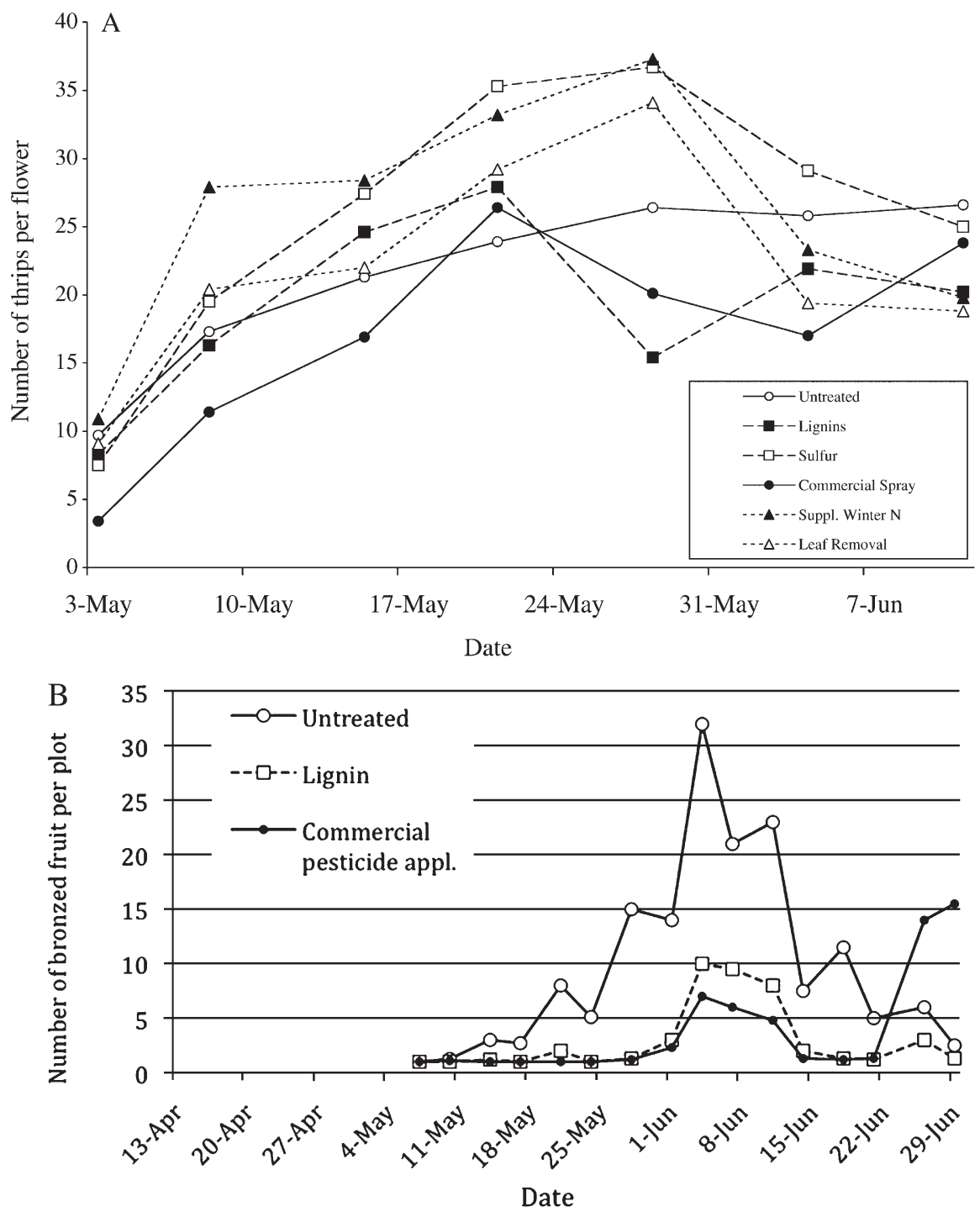

Fig. 3. Thrips abundance (A) and Type III bronzing incidence (B) in a commercial field: 2001. 
Table 4. Effect of protectant treatments on number of bronzed fruit: $2002 .^{z}$

\begin{tabular}{|c|c|c|c|c|}
\hline \multirow[b]{3}{*}{ Treatment } & \multicolumn{4}{|c|}{ Nonbronzed and bronzed (T3B) fruit (mean \pm SEM) } \\
\hline & \multicolumn{2}{|c|}{10 July } & \multicolumn{2}{|c|}{17 July } \\
\hline & Nonbronzed & T3B & Nonbronzed & T3B \\
\hline Untreated & $25.2 \pm 2.2$ & $2.2 \pm 1.3$ & $25.3 \pm 1.8$ & $1.5 \pm 1.0$ \\
\hline Lignin Reax 83A & $29.2 \pm 1.2^{y}$ & $0.3 \pm 0.5^{y}$ & $27.2 \pm 1.7^{y}$ & $0.7 \pm 0.5$ \\
\hline Lignin Kraftsperse $25 \mathrm{M}$ & $28.0 \pm 2.2^{y}$ & $0.3 \pm 0.5^{y}$ & $27.5 \pm 2.7^{y}$ & $0.2 \pm 0.4^{y}$ \\
\hline Lignin combination & $28.3 \pm 1.2^{\mathrm{y}}$ & $0.8 \pm 1.2$ & $28.2 \pm 1.2^{y}$ & $0.2 \pm 0.4^{y}$ \\
\hline Thiolux sulfur & $25.8 \pm 2.6$ & $1.7 \pm 2.3$ & $26.5 \pm 2.4^{y}$ & $1.0 \pm 1.5$ \\
\hline Commercial pesticide application & $25.8 \pm 2.4$ & $1.5 \pm 1.4$ & $23.8 \pm 3.3$ & $1.5 \pm 1.2$ \\
\hline \multirow[t]{3}{*}{ Leaf removal } & $24.8 \pm 2.2$ & $2.5 \pm 1.0$ & $24.0 \pm 3.2$ & $2.0 \pm 0.9$ \\
\hline & $F=4.160$ & $F=2.652$ & $F=2.960$ & $F=3.281$ \\
\hline & $P=0.0029$ & $P=0.0316$ & $P=0.0192$ & $P=0.0115$ \\
\hline
\end{tabular}

${ }^{\mathrm{z}}$ Mean number of fruit showing no bronzing or Type III bronzing (T3B) symptoms on two evaluation dates. ${ }^{\mathrm{y}}$ Mean differs significantly $(P<0.05)$ from untreated by a pairwise $t$ test.

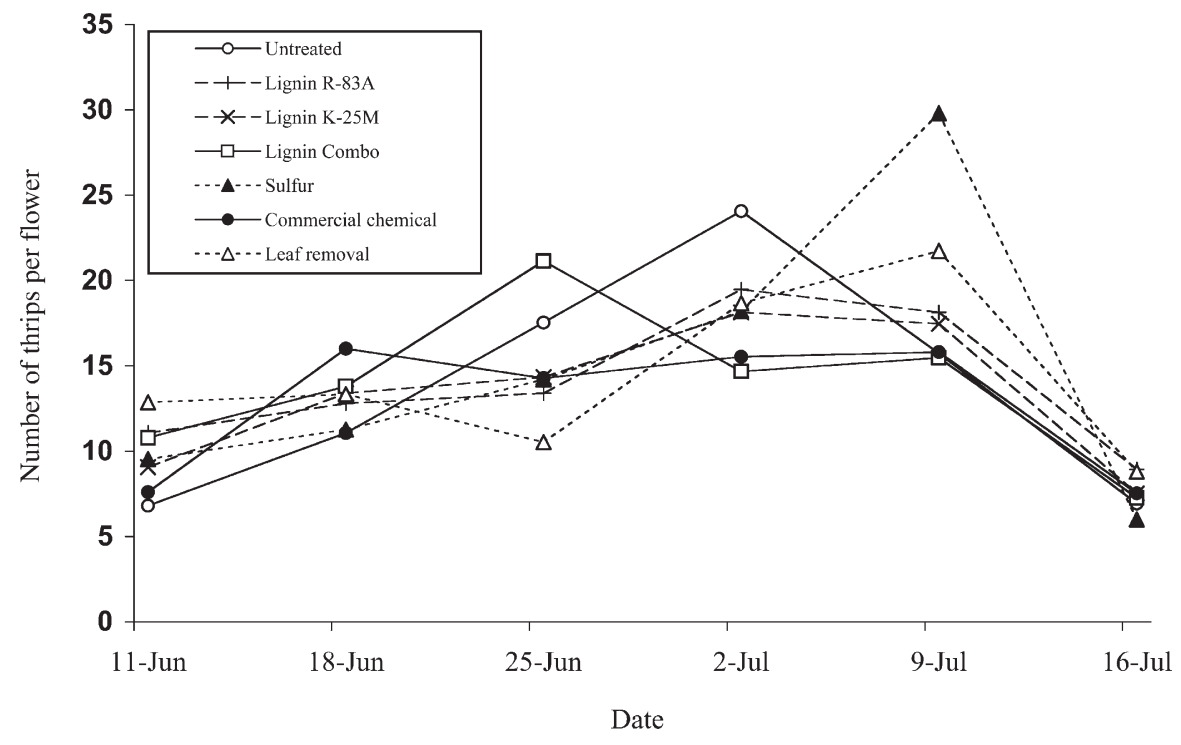

Fig. 4. Treatments and thrips densities in experimental plots in a commercial field: 2002.

T3B of strawberry fruit. Other studies have shown similar results with application of overhead water and subsequent reduction of solar injury (SI). Overhead irrigation systems are used in apple orchards to provide evaporative cooling while reducing plant stress and SI on apple fruit (Parchomchuk and Meheriuk, 1996; Recasens et al., 1988; Unrath, 1972a, 1972b). Trials in vineyards also showed reduced fruit damage and higher quality of grapes with the use of overhead sprinklers during periods of high temperatures (Gilbert et al., 1970).

In contrast to the assumption that thrips are responsible for all bronzing problems, our findings indicated that greater thrips densities were not associated with increased T3B incidence. T3B incidence was essentially the same for plots in which pesticide applications resulted in reduced thrips densities as for nontreated plots that had greater thrips densities. In 2001, thrips densities were similar for most of the season in untreated plots and in those that were treated with conventional pesticides or lignin. However, the number of fruit with T3B in lignin- or pesticide-treated plots was lower compared with counts in untreated plots. Finally, in 2002, two lignin products and their mixture were applied to replicated plots and resulted in no significant reduction in thrips densities compared with untreated control plots. These treatments, however, resulted in fewer T3Bdamaged fruit and higher counts of fruit lacking such damage. Elsewhere, Matos and Obrycki (2004) also failed to find a correlation between thrips populations and strawberry fruit bronzing. Thrips feeding generally results in localized discoloration (Allen and Gaede, 1963; Farrar, 1936; Steiner and Goodwin, 2006); such damage should be classified as Type I bronzing (Larson et al., 2005) and not confused with T3B.

Most intriguing are consistent observations made by growers and crop consultants who report reduced problems with $\mathrm{T} 3 \mathrm{~B}$ in fields that are sprayed with insecticides and fungicides in weeks preceding periods of serious T3B incidence. Our field trial results were consistent with such observations. When a series of commercial pesticide products was applied to replicated plots, T3B incidence was significantly reduced in both 2000 and 2001. In 2001, even plants in the nonsprinkled main plots had significantly fewer T3B-damaged fruit when sprayed with commercial pesticides. In 2001, the application of commercial pesticides, lignin, and Thiolux treatments all resulted in significantly less T3B damage.
Sulfonated lignin is an inexpensive byproduct of the paper industry and is often used as a surfactant in pesticide formulations because of its dispersive properties. These lignin compounds are biodegradable and used as additives to protect chemicals against solar and ultraviolet radiation; inclusion of lignins in pesticide formulations helps to prevent breakdown, inactivation, and loss of effectiveness of active ingredients (Scher, 1999). Kraft lignin, the alkali-soluble/acidinsoluble polyphenolic polymer produced as a coproduct in the kraft wood-pulping process, is also used as a pesticide adjuvant that improves rainfastness and provides product stability by absorbing ultraviolet radiation. The addition of these materials to pesticide formulations imparts ultraviolet protection in solid formulations at levels as low as $0.5 \%$ (Scher, 1999). At the time of our study, kraft lignin products were exempt from tolerance by the U.S. Environmental Protection Agency (EPA), whereas sulfonated lignins could have been included in pesticide formulations that were registered for use on strawberries. In 2005, the U.S. EPA established 44 additional tolerance exemptions for residues of various lignosulfonate chemicals when used as inert ingredients in pesticide formulations applied to growing crops (Anonymous, 2005).

It is likely that the presence of lignin materials in our commercial pesticide, lignin, and Thiolux sulfur treatments had the direct effect of protecting strawberry fruit from exposure to ultraviolet light and solar radiation. This protection would also occur when growers apply lignin-containing pesticides before periods when solar radiation levels could be damaging to strawberry fruit. Lignins do not have insecticidal properties, and the application of these products alone or when present in the Thiolux sulfur formulation had no apparent impact on thrips populations. Future studies would be helpful in identifying other chemicals or practices that could reduce bronzing incidence. A more thorough knowledge of varietal morphology, specific ultraviolet levels, and moisture stress as they might relate to bronzing could be used for predicting periods of bronzing risk.

The ability of kraft lignin and lignosulfonates to protect against solar radiation fits well with the anatomical and histological description of T3B damage. Microscopic examination of such fruit indicates that the bronzing reaction is limited to the outermost layers of cells of the fruit cortex; bronzing is not seen deeper in receptacle tissues that are not subject to direct contact by solar radiation (Cline and Salisbury, 1966; Polito et al., 2002). These cellular developments ultimately result in loss of epidermis integrity and formation of lesions. The bronze color may possibly be the result of lack of normal pigments, accumulation of phenolic compounds, and suberization of cell walls. All these reactions suggest cell damage resulting from sun scald, ultraviolet radiation, or excessive temperatures. 
It is interesting that our shadecloth enclosure treatment (2001 commercial field site) did not reduce T3B in the nonsprinkler-cooled plots. In sprinkler-cooled plots, the shadecloth hoops had a higher incidence of T3B fruit than commercial pesticide-treated plots and plots with clear full mulch, although all three treatments were not statistically different. We noted, however, that temperatures inside of the shadecloth enclosure were sometimes 3 to $5{ }^{\circ} \mathrm{C}$ greater than the outside ambient temperatures. Because the shadecloth coverings completely enclosed the beds and blocked breezes, the plants and fruit could actually have been subject to increased heat stress despite being shaded from direct sunlight. This environmental dynamic could account for the T3B levels found with this treatment.

Solar injury of fruit resulting from sun scald, ultraviolet radiation, and elevated temperatures is documented for many crops. SI is related to the absorption of solar radiation by fruit tissues and resulting symptoms resulting from intolerance of high temperatures or levels of ultraviolet and other radiation (Barber and Sharpe, 1971; Foley, 1963; Stapleton, 1992). SI has been described on fruits such as apple, blueberry, muskmelon, Crenshaw melon, cucumber, pear, pepper, raspberry, and tomato (Foley, 1963; Glenn et al., 2002; Khemira et al., 1993; Kossuth and Biggs, 1978; Lipton, 1977; Rabinowitch et al., 1983; Renquist et al., 1987). Similar to our experience with lignincontaining materials, studies on other crops have used materials in an attempt to shield susceptible fruit tissues from solar radiation (Glenn et al., 2002; Lipton, 1977).

T3B continues to occur in California and causes limited to significant crop losses depending on the particular year, location, and the cultivar being grown. Growers can better manage T3B by knowing that this problem is triggered by environmental stresses such as extreme solar radiation and high temperatures. Strawberry plants will be predisposed to such problems if plant vegetative growth was limited by winter conditions or by inappropriate farming practices (Larson et al., 2005). The timing and deployment of appropriate bed mulch systems, nitrogen-fertility regimes, irrigation management practices, and application of pesticides used in the regular course of pest management can significantly reduce losses resulting from T3B. Reduction of plant stress and manipulation of the environment surrounding plant foliage by applying brief periods of overhead sprinkling can reduce T3B damage, although the benefit may be offset by an increase in fruit rots and diseases.

\section{Literature Cited}

Allen, W.W. and S.E. Gaede. 1963. The relationship of Lygus bugs and thrips to fruit deformity in strawberries. J. Econ. Ent. 56:823-825.

Anonymous. 2005. Lignosulfonates: Exemptions from the requirements of a tolerance. Fed. Regist. 70:43309-43313.

Barber, H.N. and P.J.H. Sharpe. 1971. Genetics and physiology of sunscald of fruits. Agr. Meteorol. 8:175-191.

Bordelon, B., M. Ellis, and R. Weinzierl. 1999. Iowa commercial small fruit and grape spray guide 1999. Iowa State Univ. Extension.

Cline, M.G. and F.B. Salisbury. 1966. Effects of ultraviolet radiation on the leaves of higher plants. Rad. Biol. 6:151-163.

Farrar, M.D. 1936. Effect of thrips on pollination and blossom blight in strawberries. J. Econ. Entomol. 29:483-486.

Foley, R.F. 1963. A physiological disturbance caused by solar ultra-violet radiation that is affecting some vegetable crops in Idaho. Amer. Soc. Hort. Sci. 83:721-727.

Gilbert, D.E., J.L. Meyer, J.J. Kissler, P.D. La Vine, and C.V. Carlson. 1970. Evaporation cooling of vineyards. Calif. Agr. 24:12-14.

Glenn, D.M., E. Prado, A. Erez, J. McFerson, and G.J. Puterka. 2002. A reflective, processedkaolin particle film affects fruit temperature, radiation reflection, and solar injury in apple. J. Amer. Soc. Hort. Sci. 127:188-193.

Khemira, H., P.B. Lombard, D. Sugar, and A.N. Azarenko. 1993. Hedgerow orientation affects canopy exposure, flowering, and fruiting of 'Anjou' pear trees. HortScience 28:984-987.

Kossuth, S.V. and R.H. Biggs. 1978. Sunburned blueberries. Proc. Fla. State Hort. Soc. 91:173175.

Larson, K.D., S.T. Koike, and F.G. Zalom. 2005. Bed mulch treatment affects strawberry fruit bronzing and yield performance. HortScience 40:72-75.

Larson, K.D., S.T. Koike, and F.G. Zalom. 2006. Polyethylene mulch, deficit irrigation, overhead sprinkling, and strawberry fruit bronzing. Acta Hort. 708:51-57.
Lipton, W.J. 1977. Ultraviolet radiation as a factor in solar injury and vein tract browning of cantaloupes. J. Amer. Soc. Hort. Sci. 103:32-36.

Lynch, K. and R. Tremblay. 1995. Fruit bronzing of strawberry. New Brunswick Dept. Agr. Fact Sheet.

Maas, J.L. (ed.). 1998. Compendium of strawberry diseases. Amer. Phytopathol. Soc., St. Paul, $\mathrm{MN}$.

Matos, B. and J.J. Obrycki. 2004. Influence of thrips on bronzing of strawberry fruit. HortScience 39:1343-1345.

Parchomchuk, P. and M. Meheriuk. 1996. Orchard cooling with pulsed overtree irrigation to prevent solar injury and improve fruit quality of 'Jonagold' apples. HortScience 31:802-804.

Polito, V.S., K.D. Larson, and K. Pinney. 2002. Anatomical and histochemical factors associated with bronzing development in strawberry fruit. J. Amer. Soc. Hort. Sci. 127:355-357.

Processing Strawberry Advisory Board of California. 2008. 2008 annual report. Processing Strawberry Adv. Board Calif., Watsonville, CA.

Rabinowitch, H.D., M. Friedmann, and B. Ben-David. 1983. Sunscald damage in attached and detached pepper and cucumber fruit at various stages of maturity. Sci. Horticult. 19:9-18.

Recasens, J.R., D.I. Recasens, and J. Barragan. 1988. Sprinkler irrigation to obtain a refreshing microclimate: Effect on fruit growth rates and quality of 'Jonee' and 'Golden Smoothie' apples. Acta Hort. 228:197-202.

Renquist, A.R., H.G. Hughes, and M.K. Rogoyski. 1987. Solar injury of raspberry fruit. HortScience 22:396-397.

Scher, H.B. 1999. Controlled-release delivery systems for pesticides. CRC Press, Boca Raton, FL.

Stapleton, A.E. 1992. Ultraviolet radiation and plants: Burning questions. Plant Cell 4:13531358.

Steiner, M.Y. and S. Goodwin. 2006. Getting a grip on thrips in strawberry. Acta Hort. 708:109114.

University of California. 2008. Integrated pest management for strawberries. 2nd Ed. Publication 3351. UC IPM.

Unrath, C.R. 1972a. The evaporative cooling effects of overtree sprinkler irrigation on 'Red Delicious' apples. J. Amer. Soc. Hort. Sci. 97: $55-58$.

Unrath, C.R. 1972b. The quality of 'Red Delicious' apples as affected by overtree sprinkler irrigation. J. Amer. Soc. Hort. Sci. 97:58-61.

Williams, R.N., M.S. Ellis, S.S. Fickle, and C.M. Felland. 1999. Monitoring flower thrips activities in strawberry fields at two Ohio locations. Ohio Agr. Res. Center Special Circular 299:82-86. 